\title{
Developing Human Rights at Sea
}

\author{
Steven Haines \\ School of Law and Criminology, University of Greenwich, London, \\ United Kingdom
}

\section{Introduction*}

International human rights law (IHRL) is a recent addition to the general body of international law. Despite the significance of the 1948 Universal Declaration of Human Rights, ${ }^{1}$ the law based upon it did not achieve meaningful substance until conventional law dealing with human rights had entered into force and international conditions had allowed for the customary acceptance of the rules it contained..$^{2}$ The 1970s were an important period in the IHRL narrative. ${ }^{3}$ The two international human rights covenants from 1966 entered into force in 1976, Amnesty International received the Nobel Peace Prize in 1977 and Human Rights Watch was founded (as Helsinki Watch) the following year. ${ }^{4}$ These two non-governmental organizations (NGOs) have since been the

* The author is most grateful to the following colleagues for reviewing and commenting on an advanced draft of this article: Dr. Sofia Galani, David Hammond Esq., Ms. Fiona Laurence, Professor Olga Martin-Ortega, Ms. Elizabeth Mavropoulou, Professor Irini Papanicolopulu, and Professor Anna Petrig. He is also most grateful to the Ocean Yearbook's anonymous reviewers whose comments prompted serious reflection and led to important improvements in the final text. Any shortcomings remain entirely the author's responsibility. Email: s.haines@gre.ac.uk.

1 Universal Declaration of Human Rights, 10 December 1948, available online: <https://www .un.org/en/universal-declaration-human-rights/>.

2 The Universal Declaration, as a United Nations General Assembly (UNGA) resolution, while not legally binding and not a formal source of international law, has since been regarded as the founding document of international human rights law (IHRL). See S. Moyn, The Last Utopia: Human Rights in History (Cambridge, Mass: Harvard University Press, 2010), pp.183-185.

3 The Universal Declaration was, admittedly, followed rapidly by the European Convention for the Protection of Human Rights and Fundamental Freedoms, available online: <https:// www.echr.coe.int/Documents/Convention_ENG.pdf>, which was adopted in 1950, entering into force in 1954. It was a regional treaty, however, and not binding on States outside the Council of Europe area.

4 The two international covenants agreed to in 1966 are on: Economic, Social and Cultural Rights, available online: <https://www.ohchr.org/EN/ProfessionalInterest/Pages/CESCR .aspx>; and Civil and Political Rights, available online: <https://www.ohchr.org/en/pro fessionalinterest/pages/ccpr.aspx>. Helsinki Watch was joined by Americas Watch (1981), Asia Watch (1985), Africa Watch (1988), and Middle East Watch (1989) and, in 1988, the 
principal civil society monitoring and advocacy bodies advancing the cause of human rights globally, and they contributed significantly to the growing influence of human rights from the 1970 on onwards.

The emergence of IHRL prompts questions about its influence on the normative framework for ocean governance. As the 1970s were important years for the development of IH RL, so too, of course, were they significant for the development of the contemporary law of the sea, with the Third United Nations Conference on the Law of the Sea (UNCLOS III) meeting from December 1973 onwards. ${ }^{5}$ In reflecting on the parallel developments in IH RL and the law of the sea during the 1970s, one might assume there would be a measure of mutual influence. But that was not the case. Professor Bernard Oxman, a notable United States participant in the UNCLOS III negotiations, went so far in 1998 as to suggest that a great many of the provisions of the 1982 United Nations Convention on the Law of the Sea (UNCLOS) could be interpreted as privileging human rights. Ultimately, however, he was forced to concede that "It is unlikely that [UNCLOS] or the law of the sea more generally, will be accorded a central role in the history of the international law of human rights." 6

International human rights law only became truly influential internationally after the end of the Cold War and the last decade of the twentieth century. Only since then has it gained significant relevance across most other specialist areas of international law. Indeed, for many today, IH RL is central to both the body and the purpose of public international law. ${ }^{7}$ Given that this is now generally the case, there are several questions we might pose about the relationship between IHRL and the law of the sea. What influence have IHRL and the law of the sea had on each other during the last two decades? To what extent is IHRL applied effectively on the seas and oceans and is it having a positive effect on the lives of people who find themselves at sea? How are human rights standards monitored and enforced at sea? What are the prospects for improving human rights compliance at sea into the future? These are extremely important questions because it is increasingly apparent that human rights standards are not being maintained and protected at sea to the degree they should be.

organization formally adopted the all-inclusive name Human Rights Watch, see $<$ https:// www.hrw.org/our-history>.

5 The initial meeting of UNCLOS III was convened in New York in mid-December 1973, but was devoted to procedural issues. The Conference did not begin to address substantive issues until the following summer (between June and August 1974) in Caracas.

6 B. Oxman, "Human rights and the law of the sea," Columbia Journal of Transnational Law 36 (1998): 399-429, p. 429. I am grateful to Anna Petrig for pointing out this article to me.

7 Moyn, n. 2 above, pp. $176-177$. 
Far too many men, women and children are subject to serious abuse and are deprived of their human rights without effective remedy.

The evidence of that abuse is accumulating on a daily basis. ${ }^{8}$ People are victims of slavery at sea, many of them forced to work for years without pay on board fishing vessels thousands of miles away from their homes. Seafarers working on board merchant ships globally are subjected to substandard working conditions, and their physical and mental well-being is under constant threat. This has been particularly highlighted during the CoviD-19 pandemic, during which an international crew change crisis developed as aviation hubs closed down and seafarers found themselves extended in their roles, many indefinitely. Some find themselves abandoned in foreign ports with no pay and no way home. Far too many disappear without trace-missing seafarers whose families have no idea what has befallen them. People trafficking and migrant smuggling is a profitable enterprise for unscrupulous criminal gangs. There is much unreported crime on board cruise ships, including disturbing instances of sexual assault. These crimes are rarely investigated by competent and responsible authorities, frequently occur in situations that are jurisdictionally confusing, and many of their victims are denied justice in the wake of the abuse to which they have been subjected. Such abuses are occurring far too frequently and some are a constant feature of life at sea. Unfortunately, the seas and oceans do not constitute a "safe space" for those engaged on legitimate maritime activity. More worryingly still, some of those present at sea are there against their will and are profoundly vulnerable to the whims and unlawful practices of criminal gangs taking advantage of what remains an almost anarchic environment. It is profoundly disturbing that slavery and piracy, once assumed to be consigned to history, are still thriving at sea. This is a situation that demands change and the development of an international program of action to achieve it.

The purpose of this article is to trace the development of the law relating to human rights at sea, to describe its current structure and to set out a potential future approach to advocacy, compliance, monitoring and enforcement. To do this, the article first discusses the emergence of a relationship between the law of the sea (as the principal normative framework for ocean governance) and IHRL. It includes a brief account of past literature on the subject. It then describes what might be referred to as the "special regime" for human rights at sea. This is followed by comment on enforcement jurisdiction and the responsibilities of States, be they port States, coastal States or flag States. Finally,

8 See the newsfeed and the various detailed reports on human rights abuses at sea on the Human Rights at Sea website: <https://www.humanrightsatsea.org >. 
we turn to a proposal for a systematic program of action to take forward the cause of human rights protection at sea. This includes mention of the Geneva Declaration on Human Rights at Sea, first promulgated in 2019, but still undergoing progressive development.

The author is by no means a detached or objective observer of this subject. As a Trustee of the British-based charity and NGO Human Rights at Sea (HRAS), he has been involved in the development of the Geneva Declaration on Human Rights at Sea and is very much engaged in human rights advocacy in relation to the seas and oceans. This article may be vulnerable to some criticism on that account and regarded as a piece of advocacy rather than an objective academic analysis. We accept that risk but argue that a view of the oceans from a human rights perspective is both long overdue and a legitimate challenge to more well-established approaches. Criticism of this article is welcome. It will be for the good if it is itself challenged, resulting in a robust debate about its subject. The treatment and protection of people at sea is a vitally important aspect of the social dimension of the oceans. We estimate there are over 30 million men, women and children actively at sea, including fishers, merchant seafarers, offshore hydrocarbon industry workers and passengers on board cruise ships, as well as many who are not there by choice. ${ }^{9}$ They all have human rights that require protection.

\section{Human Rights and the Law of the Sea}

UNCLOS III did not include human rights on its otherwise extensive agenda. In 1978 , the Law of the Sea Institute addressed "neglected issues" in the law of the sea. Despite the previous entry into force of the two international covenants, in 1976, human rights still was not considered important enough to mention. ${ }^{10}$ UNCLOS contains no explicit reference to human rights. The late Professor D.P. O'Connell's magisterial and comprehensive two-volume treatment of the history and development of the law of the sea, published posthumously in the

9 The author's estimate (based on UN Food and Agriculture Organization, International Chamber of Shipping, cruise industry and other reasonably reliable sources) includes almost 30 million fishers, around 1.7 million merchant seafarers, up to 60o,ooo cruise passengers at any one time, as well as approximately 200,000 offshore industry workers. The seas are not densely populated, but nor are they as sparsely populated as some may imagine.

10 See J. King Gamble Jr., Law of the Sea: Neglected Issues (Hawaii: Law of the Sea Institute, 1979), Proceedings of the Law of the Sea Institute Twelfth Annual Conference, The Hague, 23-26 October 1978. Critiques by Buzan and Johnston are at pp. 503-513. 
immediate aftermath of UNCLOS III, also made no mention of the subject." Nor have recent studies attempted to imply in retrospect that human rights were a notable influence on developments at UNCLOS III. ${ }^{12}$

What is a little surprising, however, is that even now, almost four decades on, the standard texts on the law of the sea still avoid mention of IHRL. ${ }^{13}$ As an example, Tanaka does mention "humanity at sea" but this is concentrated in two short paragraphs dealing with ships in distress, search and rescue, coastal State responsibilities for the safety of navigation and the duty to render assistance. These do, of course, have some human rights relevance in relation to the right to life, but only marginally. Oddly, and as if to confirm that he was not consciously referring to IHRL in those paragraphs, Tanaka chooses not to mention therein Article 99 of UNCLOS dealing with slavery at sea, the most obvious provision of the entire Convention having IHRL significance. ${ }^{14}$

Also surprising is the absence of any significant treatment of IHRL in the otherwise comprehensive and valuable 2013 text by Kraska and Pedrozo on the international law of maritime security. "Human rights" are at least listed in the index of their volume, but it leads to four single mentions on just three pages in a volume of almost a thousand pages. ${ }^{15}$ Human rights are also largely ignored in the section on maritime security in the International Maritime Law Institute (IMLI) manual on international maritime law published in 2014. ${ }^{16}$ The decision not to link human rights and maritime security is surprising, given the extent to which serious human rights concerns have been raised by the conduct of security operations since the $9 / 11$ terrorist attacks on New York and Washington, DC in 2001.

Evidence from the relevant literature, therefore, points to a less than adequate coverage of the maritime application of IHRL prior to the middle of the

11 D. O'Connell, The International Law of the Sea, in two volumes (edited by I. Shearer) (Oxford: Clarendon Press, 1982 and 1984).

12 See, for example, J. Harrison, Making the Law of the Sea: A Study in the Development of International Law (Cambridge: Cambridge University Press, 2011).

13 Recent examples of standard texts are Y. Tanaka, The International Law of the Sea (Cambridge: Cambridge University Press, 2012); and D. Rothwell and T. Stephens, The International Law of the Sea, 2nd ed. (Oxford: Hart, 2016).

14 See Tanaka, n. 13 above, pp. 15-16. He does, to be fair, go on to deal with slavery at pp. $79^{-80}$ and $160-161$.

15 J. Kraska and R. Pedrozo, International Maritime Security Law (Leiden and Boston: Martinus Nijhoff, 2013), pp. 549, 659, 913.

16 M. Fitzmaurice, N.A. Martínez and R. Hamza, eds., The IMLI Manual on International Maritime Law Volume III: Marine Environmental Law and Maritime Security Law (Oxford: Oxford University Press, 2016), p. 510. To be fair it should be noted that Papanicolopulu has a full chapter on IH RL and the law of the sea in IMLI Manual Volume I, see n. 31 below. 
last decade. This can be regarded as both a cause and an effect of the international community's failure fully to notice and respond to significant human rights abuses at sea. While ocean governance specialists appear not to have taken full account of IHRL, they are not entirely to blame. The substantial and growing community of IHRL lawyers and advocates also appears not to have fully appreciated the scale of human rights abuses at sea and the particular challenges they pose to the global human rights system. The very latest IHRL textbook, published as this article was being prepared, still devotes no chapter to human rights at sea. ${ }^{17}$

One explanation is structural. It is States that bear responsibility for human rights standards. Their responsibilities are largely related to their exercise of territorial jurisdiction (notwithstanding the increasing relevance of extraterritorial jurisdiction in recent years). ${ }^{18}$ The monitoring of compliance is, first and foremost, a responsibility of the UN Human Rights Council and various treaty bodies. Their focus tends to be on compliance within the territory of States. Civil society monitoring reflects this. Amnesty International and Human Rights Watch have developed substantial and thorough monitoring and reporting mechanisms, including deploying dedicated staff into most regions and countries globally. Each has a deliberate "country focus" and this may have worked against a full appreciation of the importance of human rights standards beyond territorial limits. While it would be quite wrong and patently unfair to suggest that they have ignored human rights at sea altogether, neither NGO has monitored them generally or researched them to the extent they have monitored standards ashore. The apparent result has been a less than full appreciation of the scale of abuse at sea. The oceans have not been entirely "out of sight and out of mind," but the difficulties of monitoring compliance at sea have allowed far too many abusers to act with relative impunity.

Until now, IHRL perspectives have not influenced the development of the law of the sea as much as they might have done, and equally, the law of the sea has not influenced the development of IHRL. The two bodies of law appear

\footnotetext{
17 J. Donnelly and D. Whelan, International Human Rights, 6th ed. (Abingdon: Routledge, 2020).

18 Extraterritorial responsibility in IHRL is increasingly a feature of IHRL with States now being held responsible for breaches of human rights well beyond the limits of their territorial jurisdiction. For a most pertinent example, see European Court of Human Rights, Hirsi Jamaa and Others v. Italy [GC], Application No. 27765/o9, reported online: $<$ https://www.asylumlawdatabase.eu/en/content/ecthr-hirsi-jamaa-and-others-v-italy -gc-application-no-2776509>.
} 
to have existed and developed quite separately. ${ }^{19}$ This is an unfortunate consequence of the supposed fragmented nature of international law, a serious concern addressed by the International Law Commission (ILC) in 2006. It pointed to the existence of separate specialist areas of law posing a serious challenge to the unified nature and working of international law. Fragmentation sees the separation of "law into highly specialized 'boxes' that claim relative autonomy from each other and from general law."20

As the general body of international law has increased in volume, complexity and sophistication, those working in the field have, through necessity, become increasingly specialized. Both the law of the sea and the more recently developed IH RL have demanded increasingly specialist focus for this reason. This has been particularly the case in recent decades. Each has evolved processes specific to it, including in relation to the judicial function. In the case of IHRL, the development of the law has been especially influenced by the jurisprudence of the various regional human rights courts and tribunals, as well as by the practice of treaty monitoring bodies. In contrast, and despite the increasing jurisprudence of the Hamburg Law of the Sea Tribunal, ${ }^{21}$ developments in the law of the sea have been principally through new conventional law and State practice leading to the development of customary law.

While the separate development of these two bodies of international law to date is just about understandable, it ought not to be allowed to continue. There is a clear need for human rights to be recognized, complied with and enforced within the evolving framework for ocean governance. There is a simple rationale for this: the law of the sea has influence over 70 percent of the Earth's surface and the 30 million souls present in that vast area have fundamental human rights requiring protection. While that has been the case for some time, it has not so far led to a general recognition of the applicability of IHRL at sea. There are, however, indications that this may be about to change.

\footnotetext{
19 Professor Oxman, in his 1998 paper, referred to the groupings of specialist lawyers as "guilds." See Oxman, n. 6 above, pp. 399-40o.

20 M. Koskenniemi, Report on Fragmentation of International Law: Difficulties Arising from the Diversification and Expansion of International Law (Geneva: International Law Commission, 2006).

21 See A. Petrig and M. Bo, "The International Tribunal for the Law of the Sea and human rights," in Human Rights Norms in 'Other' International Courts, ed., M. Sheinin (Cambridge: Cambridge University Press, 2019), pp. 353-411.
} 


\section{The Beginnings of "Human Rights at Sea"}

Despite the rising profile of human rights from the 1970s onwards, legal research and analysis on human rights at sea did not begin to emerge until around the turn of the millennium..$^{22}$ This is not to say that the welfare of people at sea before this was not a matter of concern. On the contrary, it certainly was. It did not require an academic legal interest or a commitment to IHRL to generate support for the welfare of seafarers. Tangible and effective action dates back to the 19th century at least. One of the oldest welfare organizations looking out for the interests of seafarers is the Seamen's Church Institute (SCI) founded in the United States in 1834. The International Transport Workers' Federation (ITF) dates back to 1896 and the Apostleship of the Sea was founded in Glasgow in 1922. A combination of labor and religious organizations have long been prominent in providing support to those seafarers who need it. The IT F remains the principal focus for labor unions globally and the International Seafarers' Welfare Assistance Network (ISWAN) has a total of seventy-six members which, to quote from its website, represent

an extensive network of international organisations committed to improving the welfare of seafarers. Our members reflect the diversity present in the shipping industry today and include important organisations such as the International Chamber of Shipping (ICS), the International Christian Maritime Association (ICMA), and the International Transport Workers' Federation (ITF). From shipping companies to unions, insurance groups to welfare organisations, our members possess a wealth of different experience and include key influencers in the field of seafarers' welfare. ${ }^{23}$

In many ways, given the history of their sector, the various welfare and labor organizations could be seen as spearheading the process, to which IHRL applied at sea is the latest contributor. They certainly remain a vital part of the overall humanitarian effort to protect those who find themselves at sea, for whatever reason. Some are closely associated with the labor unions and have a particular obligation to their members, with a focus on the global shipping industry, but there are also many whose concerns are much broader than that.

22 Although the subject had been raised as early as the late-198os. See L. Sohn, "International law of the sea and human rights issues," in The Law of the Sea: What Lies Ahead?, ed., T. Clingan, Proceedings of the Law of the Sea Institute 2oth Annual Conference, University of Miami, 1986 (Honolulu: Law of the Sea Institute, 1988), pp. 52-71.

23 See International Seafarers' Welfare and Assistance Network (ISWAN), "Join ISWAN," available online: <https://www.seafarerswelfare.org/about/join-iswan>. 
In terms of people, shipping employs around five percent of those who earn their living at sea, the bulk of whom are fishers who are less well catered for by the welfare organizations. Arguably, what the emergence of IH RL could bring to the maritime environment is a set of internationally recognized standards reflecting fundamental rights common across the piste. Until the last years of the 2oth century, that was certainly missing. It began to emerge as the new millennium approached.

In 1999, the late Professor Alastair Couper published a short volume, against an IHRL backdrop, detailing abuses within the shipping industry. ${ }^{24}$ In 2000 , the International Commission on Shipping produced a report dealing with crimes committed against mariners, which also described their legal status. ${ }^{25}$ Moves were also afoot that would lead to the negotiation of the 2006 Maritime Labour Convention, focused on seafarers' rights and employment issues within the shipping industry. This has an obvious overlap with developing IH RL. ${ }^{26}$

Informed by this focus on seafarers' rights, the ITF approached the British Institute of International and Comparative Law (BIICL) to research the full range of laws and regulations affecting the working life of seafarers. The eventual outcome of that project was the volume entitled Seafarers' Rights published in 2005. ${ }^{27}$ Its core purpose was to outline the legal framework for dealing with abuses and malpractices within the shipping industry. Issues of concern were listed by the late Judge Thomas Mensah in the volume's foreword. They included

illegal and fraudulent recruitment practices; the exploitation of ignorant and vulnerable persons by the imposition of unlawful fees and burdensome employment conditions; the blacklisting of seafarers who attempt to assert their rights or seek assistance to obtain redress for unfair treatment, the exertion of pressure on seafarers and their dependants to sign away their rights to full compensation under the law, physical and mental abuse of seafarers at sea, including subjection to substandard living conditions and denial of appropriate medical care; non-payment of wages;

24 A. Couper, Voyages of Abuse: Seafarers, Human Rights and International Shipping (London: Pluto Press, 1999).

25 International Commission on Shipping, Ships, Slaves and Competition: An Inquiry into Ship Safety (Charlestown, NSW: ICONS, 2000).

26 See the account in P. Payoyo, "Seafarers' human rights: Compliance and enforcement," in The Future of Ocean Governance and Capacity Development: Essays in Honor of Elisabeth Mann Borgese, ed., International Ocean Institute (Leiden: Brill, 2018), pp. 468-472.

27 D. Fitzpatrick and M. Anderson, eds., Seafarers' Rights (Oxford: Oxford University Press, 2005). 
delays in paying entitlements to families; and abandonment of seafarers at locations far from their homes or the places of recruitment. ${ }^{28}$

This was and remains an extremely important volume. Its analysis ranged across both international labor rights outlined in over fifty maritime laborrelated conventions, mostly negotiated under the auspices of the International Labour Organization (ILO), safety of navigation and ship safety-related conventions negotiated under International Maritime Organization (IMO) auspices, as well as the various sources of international and regional human rights law. It was a commendable first attempt at a study of seafarers' rights, although it did not represent a comprehensive treatment of human rights at sea. It is stressed that this is an observation and emphatically not a criticism. The content of the volume was entirely consistent with its stated purpose, which was to focus on those rights applicable within the international shipping industry. Indeed, the point was made in the editors' preface, that the rights of others working at sea, including fishers, were not the focus of the volume.

By coincidence, in the same year that Seafarers' Rights was published, one of the IMO shipping-related conventions was amended and an IH RL consideration introduced into its text, the first occasion on which this had happened. The convention in question was the 1988 Convention on the Suppression of Unlawful Acts Against the Safety of Navigation (the suA Convention) which was amended in 2005 in the light of a reassessment of maritime security following the $9 / 11$ attacks on New York and Washington, DC in 2001. The relevant new provision (paragraph 10 of Article 8bis), in dealing with ship boarding, requires the boarding State to take "due account of the need not to endanger the safety of life at sea, and to act in a manner that preserves the basic human dignity of all persons on board the ship and that complies with international human rights law." 29

Despite this brief mention of IHRL in the 2005 SUA Convention and the specific seafarers' rights agenda, it is only really in the immediate past decade that we have seen a notable emergence of academic research and published literature bringing the law of the sea and IHRL together. This was prompted initially by media and political interest in high profile activities at sea, of particular significance being the constabulary response to Somali-based piracy

28 T. Mensah, "Foreword," id., p. v. Judge Thomas Mensah (1932-2020), a most distinguished figure in the law of the sea community, died on 7 April 2020 as this article was being prepared. His contribution to scholarship in this field was immense and it is an honor to have this opportunity to acknowledge his life of great value and achievement.

29 See the "Commentary" on the suA Convention in Kraska and Pedrozo, n. 15 above, p. 837 (emphasis added). 
by multinational naval forces deploying into the Indian Ocean. There were various human rights issues raised in this context, and it is not surprising that academic lawyers began to analyze the legal consequences of piracy and the international response to it. A second and enduring high-profile issue has been irregular migration by sea, very much in the news because of migrant flows into Europe across the Mediterranean from the Middle East and North Africa (MENA).

Guilfoyle wrote of counter-piracy and human rights in 2010, and Geiss and Petrig published a volume on the same theme the following year. ${ }^{30}$ Papanicolopulu noted in 2012 that UNCLOS had failed to deal with the protection of people at sea and, two years later, contributed a chapter on human rights and the law of the sea to the IMLI's major study into maritime law. ${ }^{31}$ In the same year, Petrig published on human rights issues to do with the arrest, detention and the transfer/rendition of piracy suspects. ${ }^{32}$ In 2016, Galani also focused on the human rights of seafarers in the context of Somali piracy. ${ }^{33} \mathrm{In}$ the same year, Mann wrote of the relationship between the law of the sea and IHRL, but focused on irregular maritime migration. ${ }^{34}$ By 2016, IHRL and the law of the sea were increasingly being considered together. That year, Wilson published an important and notable paper on IHRL and maritime law enforcement. Since then, the annual NATo Maritime Operational Law Conference has regularly included panel sessions dealing with IHRL and maritime operations. ${ }^{35}$ Recently, Petrig and Bo have written about the consideration of

30 D. Guilfoyle, "Counter-piracy law enforcement and human rights," International and Comparative Law Quarterly 59 (2010): 140-179; R. Geiss and A. Petrig, Piracy and Armed Robbery at Sea: The Legal Frameworkfor Counter-Piracy Operations in Somalia and the Gulf of Aden (Oxford: Oxford University Press, 2011).

31 I. Papanicolopulu, "The Law of the Sea Convention: No place for persons," International Journal of Marine and Coastal Law 27 (2012): 867-874; I. Papanicolopulu, "Human rights and the law of the sea," in The IMLI Manual on International Maritime Law, Volume 1: The Law of the Sea, eds., M. Fitzmaurice and N.A. Martínez (Oxford: Oxford University Press, 2014), pp. 509-532.

32 A. Petrig, Human Rights and Law Enforcement at Sea: Arrest, Detention and Transfer of Piracy Suspects (Leiden: Brill/Martinus Nijhoff, 2014).

33 S. Galani, "Somali piracy and the human rights of seafarers," Netherlands Quarterly of Human Rights 34, no. 1 (2016): 71-98.

34 I. Mann, Humanity at Sea: Maritime Migration and the Foundations of International Law (Cambridge: Cambridge University Press, 2016).

35 B. Wilson, "Human rights and maritime law enforcement," Stanford Journal of International Law $5^{2}$ (2016): 243-319. The NATo Maritime Operational Law Conference is an annual event conducted under the auspices of the Centre of Excellence for Operations in Confined and Shallow Waters in Kiel, with the events being physically hosted by different NATO member States each year. 
human rights in the jurisprudence of the International Tribunal for the Law of the Sea (ITLOS), and Galani has dealt with the European Union's responsibilities in relation to human rights in its adjacent waters. ${ }^{36}$

While academic legal interest in human rights at sea was stirring, two significant civil society organizations arrived on the scene. The first was Seafarers' Rights International (SRI), which was launched in 2010. When the IMo Secretary-General spoke at the launch he commented that those seafarers, "[a]s well as the natural hazards of the sea and the elements, which they have to deal with as a matter of course ... also face exceptional hazard, such as pirate attacks, unwarranted attention and abandonment." ${ }^{37}$ The main role of SRI over the past decade has been to concentrate on the rights of the almost 1.7 million seafarers working in the global shipping industry. In that effort it has worked very closely with the seafarers' unions, and in particular with the ITF, whose Secretary-General sits on SRI's Advisory Board. The executive director of SRI since its launch was previously the head of ITF's legal services department and was also the editor of Seafarers' Rights. ${ }^{38}$ Closely associated with the shipping industry and unions, SRI is also now increasing its interest in the fishing industry.

The second NGO is Human Rights at Sea (HRAS), founded in 2014 by David Hammond, a London-based barrister and former naval lawyer, who had been asked about maritime human rights and realized that little was known about the subject. Despite the ground-breaking work of SRI in relation to the rights of those working in the shipping industry, Hammond discovered a virtual vacuum of information on the application of IHRL across the maritime environment as a whole. His difficulty searching for information prompted him to found and establish HRAs. ${ }^{39}$ Since then, it has been gaining acknowledgment of its core principle that "human rights apply at sea to the same extent that

36 A. Petrig and M. Bo, "The International Tribunal for the Law of the Sea and human rights," in Human Rights Norms in 'Other' International Courts, ed., M. Sheinin (Cambridge: Cambridge University Press, 2019), pp. 353-411; S. Galani, "Assessing maritime security and human rights: The role of the EU and its Member States in the protection of human rights in the maritime domain," International Journal of Marine and Coastal Law 35, no. 2 (February 2020): 325-347.

37 Seafarers' Rights International (sRI), "Our Purpose," available online: $<$ https://seafarers rights.org/our-purpose/>.

38 The executive director of SRI is Deirdre Fitzpatrick, an experienced employment law practitioner who has been involved in a number of cases to do with the recognition of workers' unions within the shipping industry. See SRI, "SRI Resources: Deidre Fitzpatrick," available online: $<$ http://seafarersrights.org/sri_resources/deirdre-fitzpatrick/> .

39 See Human Rights at Sea (HRAS), "Chief Executive Officer," available online: <https:// www.humanrightsatsea.org/ceo/>. 
they do on land." ${ }^{40}$ HRAS is concerned with the human rights of everyone at sea and is not restricted in any geographical or sectoral sense.

The work of these two NGOs has had an important influence on the development of a human rights at sea perspective and narrative. The latter, in particular, has established a comprehensive human rights agenda, including slavery at sea, especially in the fishing industry, people trafficking and irregular migration, sexual assaults, deprivation of liberty, ${ }^{41}$ and other criminal acts on board cruise ships, as well as shipping industry issues to do with working conditions and missing seafarers. It has also focused effort on developing the maritime sector's awareness and application of the 2011 UN Guiding Principles on Business and Human Rights. ${ }^{42}$ Hammond was also responsible for initiating the process to produce the Geneva Declaration on Human Rights at Sea, which is described below and included in the Appendix to this article.

In 2018, Papanicolopulu published what is probably the most significant general contribution to the academic legal literature so far. She argues convincingly that a number of rules of international law can be regarded together as "a sui generis special regime of international law, the overarching principle of which is the duty of States to protect people at sea." The rules to which she refers are those generally understood to be the standard rules of IHRL and the relevant rules of the law of the sea. She is also conscious of the relevance of rules from "other fields of international law, including maritime law, labour law and refugee law."43 The notion of a "special regime" for human rights at sea is certainly worth examining.

40 See the Hras website, id., and the discussion below for details of the role of HRAS in monitoring and advocacy.

41 See D. Hammond and A. Petrig, Deprivation of Liberty at Sea (HRAS, 2015), available online: <https://www.humanrightsatsea.org/wp-content/uploads/2015/o6/HRAS_DoL-dps.pdf>.

42 See 2011 UN Guiding Principles on Business and Human Rights, available online: <https://www.ohchr.org/documents/publications/guidingprinciplesbusinesshr_en.pdf> and hras, "Implementing the UN Guiding Principles on Business and Human Rights in the Maritime Sector" (2018), available online: <https://www.humanrightsatsea.org/ wp-content/uploads/2018/og/HRAS-IMHR2018-Business-and-Human-Rights-Key -Facts.pdf>.

43 I. Papanicolopulu, International Law and the Protection of People at Sea (Oxford: Oxford University Press, 2018), p. 1. Papanicolopulu is a member of the Human Rights at Sea Advisory Board and joint author of the Geneva Declaration on Human Rights at Sea, discussed below. 


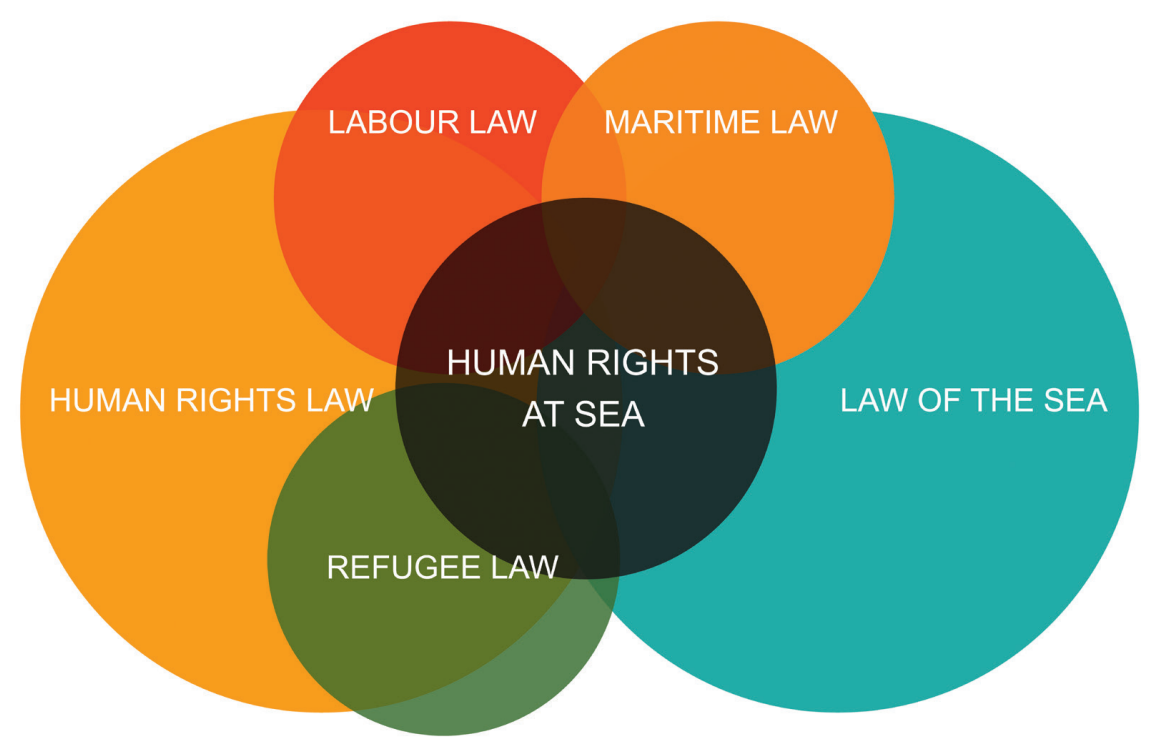

FIGURE 1 The content of human rights at sea

\section{A “Special Regime” for Human Rights at Sea?}

The ILC report on the fragmentation of international law had been concerned about the development of "special regimes," viewing their influence as a root cause of the divisions between various elements of international law. In response, Papanicolopulu argues for recognition of a rather different special regime, one that serves to draw different relevant strands of international law together, rather than allow them to drift and remain apart. The different bodies of international law she has identified as together contributing to the formation of the special regime of human rights at sea-IHRL and the law of the sea, but also maritime law, labor law and refugee law-are not exhaustive but are the most obvious ones. The pattern of their contribution to human rights at sea is illustrated in Figure $1 .{ }^{44}$ It is worth saying something about each of the areas of law represented in Figure 1, as well as mentioning one or two others that might provide some input.

44 This Venn diagram illustrating the make-up of this "special regime" has been devised by the author and drawn by Victoria Yanushevskaya especially for this article. It is purely illustrative and the relative size and degrees of overlap of the different circles are not intended accurately to convey either the importance or the degree of mutual influence of the bodies of law included. 


\section{International Human Rights Law}

It is easy to claim that IHRL applies everywhere and that it does so on the seas and oceans to the same extent that it applies ashore within the territorial jurisdiction of States. ${ }^{45}$ We know, of course, that while this is the case de jure, in practice IHRL is not applied to the same degree across the globe. It does apply universally, but it is not applied universally. There is a subtle but regrettable difference between the two, with far too many deprived of the rights to which they are entitled through both the actions and inaction of others. Human rights are universal, but behavior is not uniform, nor is it ever likely to be. There are also, of course, entirely legitimate regional differences, many generated by the jurisprudence of the various regional courts and tribunals as well as the treaties that brought them into existence. This is so, notwithstanding the willingness of individual regional judicial bodies to take account of the legal reasoning deployed in other jurisdictions.

Such differences in both law and behavior aside, one can identify the main universally applicable features of IHRL by reference to the Universal Declaration (as its "founding document") and such conventional law as is contained in the two international covenants and the other specific conventional law instruments, as follows: 46

- 1965 Convention on the Elimination of All Forms of Racial Discrimination (ICERD)

- 1966 International Covenant on Civil and Political Rights (ICCPR)

- 1966 International Covenant on Economic, Social and Cultural Rights (ICESCR)

- 1979 Convention on the Elimination of All Forms of Discrimination Against Women (CEDAW)

- 1984 Convention against Torture and Other Cruel, Inhuman or Degrading Treatment or Punishment (CAT)

- 1989 Convention on the Rights of the Child (CRC)

- 1990 Convention on the Protection of the Rights of All Migrant Workers and Members of their Families (ICMW)

- 2006 Convention for the Protection of All Persons from Enforced Disappearance (CPED)

- 2006 Convention on the Rights of Persons with Disabilities (CRPD)

45 This is the foundational principle of the NGO HRAS and it is restated in the Geneva Declaration on Human Rights at Sea.

46 UN Human Rights, Office of the High Commissioner (онснR), "The Core International Human Rights Instruments and Their Monitoring Bodies," available online: <https:// www.ohchr.org/EN/ProfessionalInterest/Pages/CoreInstruments.aspx $>$, together with the various optional protocols additional to a number of the conventions. 
All of these conventions have some relevance to the seas and oceans although, of course, the usual principles of treaty law apply in relation to both the extent to which they are conventionally binding and their relationship with State practice and customary law. The fact remains, however, that the human rights established in these conventions are not applied universally and are far too frequently ignored or abused. That is certainly the case at sea. There should be no question about the applicability of these rights at sea, but there are serious concerns about the extent to which they are complied with and enforced. Indeed, under current circumstances, it is no exaggeration to say that IHRL is often unenforceable at sea, for reasons to be explained below.

\section{The Law of the Sea}

UNCLOS is by no means the only conventional law, but it is the principal legal source and framework instrument for ocean governance. Other conventional sources include those instruments negotiated under the auspices of the IMO, including in particular (for their humanitarian purposes) the Safety of Life at Sea (SOLAS) and Search and Rescue (SAR) conventions. ${ }^{47}$ There is also the important mention of IHRL compliance requirements in the 2005 SUA Convention, discussed above. All IMO conventions are consistent with and contained within the framework provided by UNCLOS.

While the law of the sea has until recently not contained a clear focus on IHRL, there are elements of it that do resonate with human rights. As noted already, several provisions to do with the safety of navigation and search and rescue have a humanitarian dimension and are associated with the right to life. Even more obviously, Article 99 of UnCLOs, prohibiting the "transport of slaves," has profound human rights significance. All aspects of slavery (not merely their transportation) are regarded as breaches of a peremptory norm of international law. ${ }^{48}$ As an example, a fishing vessel manned by slave labor would clearly be in breach of Article 99, with prime responsibility for that resting with the flag State, but with some also resting with whatever coastal State exercises jurisdiction over the waters in which the vessel is fishing. On the high

47 International Convention for the Safety of Life at Sea, 1974 (solas 1974) International Convention on Maritime Search and Rescue, 1979 (SAR 1979). Other agreements dealing with safety at sea include the Special Trade Passenger Ships Agreement of 1971 and the Convention on the International Regulations for Preventing Collisions at Sea (COLREGS) of 1972. For a full list of International Maritime Organization (IMO) conventions/treaties and their current status see <https://www.imo.org/en/About/Conventions/ StatusOfConventions/Pages/Default.aspx $>$.

48 M. Shaw, International Law, 6th ed. (Cambridge: Cambridge University Press, 2008), p. 808. 
seas, of course, exclusive flag State jurisdiction applies. This brings us to the principle importance of the law of the sea to IHRL, which is to do with jurisdiction linked to State responsibility.

Responsibility for the protection of human rights falls to port States, coastal States and flag States, each exercising jurisdiction within one or more of the various juridical zones defined in the law of the sea. ${ }^{49}$ Port States are able to exercise jurisdiction over vessels present within their port limits which, for the most part, will be located within their internal waters. Coastal States exercise jurisdiction within the various zones adjacent to their coasts, from internal and territorial waters out to the extent of continental shelf jurisdiction. Flag States exercise jurisdiction over the vessels registered to their flag, wherever they are located and regardless of the activity in which they are engaged. If a vessel is operating in a zone of coastal State jurisdiction, it is subject to the jurisdiction of both its own State of registration and the coastal State in question. In such circumstances of overlapping jurisdictions, it will depend on the precise circumstances, and the nature of the activities prompting a response, which of the two States - the flag or the coastal—is best placed to exercise jurisdiction. Both may have a responsibility to exercise it in relation to breaches of IHRL. In many circumstances, the flag State will not be the only State able to exercise some measure of jurisdiction over vessels on its registry. When those vessels are on the high seas beyond the limits of coastal State jurisdiction, however, the flag State will have exclusive jurisdiction over them, although, as we explain below, it may not be effective in exercising this.

\section{Maritime Law}

Maritime law is a potentially confusing term. In recent years, it has been associated with shipping law (also referred to as admiralty law and the law on carriage of goods by sea), a part of private international law, much of it to do with the negotiation and execution of private (non-public) commercial agreements to carry goods by sea. In contrast, the law of the sea is taken to represent the public international law of the seas and oceans. The reason for confusion is well demonstrated by Judge David Attard's Preface to the IMLI's three volume Manual on International Maritime Law, which incorporates the law of the sea, shipping law, marine environmental law, and maritime security law. He justifies the IMLI approach as follows:

49 Generally, States have obligations to respect, protect, fulfil and promote human rights, the totality of these obligations involving a mix of positive action to achieve standards and a need to refrain from action that would breach them. For the purposes of this article, we concentrate on obligations to protect. 
While there is a trend in certain legal literature to treat the law of the sea and shipping law (or admiralty law) separately, it is submitted that these public and private branches of international maritime law have today become intimately interdependent, particularly through the emergence and influence of international maritime treaties, such as those adopted by the Iм0. ${ }^{50}$

There is most certainly truth in this. It is going too far, however, to imply that it is now routine for the literature to deal with these bodies of law together; generally, it does not. The more traditional division, between public law and private maritime law, persists. There are several standard texts dealing exclusively with shipping law. Universities still in the main teach the law of the sea and shipping law in distinct modules, with some law schools only teaching one of the two subjects. ${ }^{51}$

At first sight, maritime law appears to have very little to do with the persons involved in shipping, with the standard texts on the subject ordinarily having no sections within them dealing with either crewing or passenger issues or with either IHRL or labor law. Appearances can be deceptive, however. Maritime law assumes importance in relation to the commercial contractual backdrop to shipping activities that will inevitably have human consequences. If, for example, in the execution of commercial contracts, disputes arise and contracts are breached, the consequential litigation may have the potential adversely to affect the conduct of shipping and, therefore, the conditions and treatment of those employed at sea. The arrest of a vessel by those in dispute with its owner or charterer can leave seafarers abandoned in foreign ports, without pay and with severe difficulties obtaining repatriation to their home countries.

Both SRI and HRAS have raised concerns about the adverse effects on seafarers of commercial decisions made by shipping companies. Concrete examples of seafarer abandonment have been publicized by HRAS in reports posted on its website and on its social media accounts. They include, as examples, a case of thirty seafarers from three vessels abandoned for over two years in the United Arab Emirates and another involving eight abandoned seafarers

$5^{\circ} \quad$ IMLI Manual Volume 1, n. 31 above, p. vii.

$5^{1} \quad$ For example, J. Wilson, Carriage of Goods by Sea, 7th ed. (Harlow: Longman, 2010); S. Baughen, Shipping Law, 7th ed. (Abingdon: Routledge, 2019); P. Todd, Principles of the Carriage of Goods by Sea (Abingdon: Routledge, 2015); Y. Baatz, Maritime Law (Abingdon: Routledge, 2017); C. Hill, Maritime Law, 6th ed. (Abingdon: Routledge, 2003). None of these standard texts on the subject delve into the public international law of the sea. 
in Walvis Bay, Namibia. ${ }^{52}$ They are real cases and not hypothetical constructs. As SRI points out:

When a crew on a merchant ship is abandoned in a foreign port, a familiar pattern of events unfolds: fuel for generators runs out; salaries stop being paid; shore leave is denied; food and water stops being supplied; services provided to the ship go unpaid; often the ship owner cannot be traced or remains in the background, sometimes threatening the crew and making false promises; on board, phone cards run out of credit and seafarers are unable to call home; relationships suffer as boredom sets in and tempers flare; families of seafarers are left begging for help. ${ }^{53}$

\section{Labor Law}

There is today an extensive body of international maritime labor law, negotiated by States over many years principally, but not exclusively, to do with the working conditions of seafarers within the global shipping industry. In that context, negotiations have taken account of industry opinion expressed by shipping companies collectively through such organizations as the International Chamber of Shipping, and by workers' unions expressed collectively though such bodies as the ITF. The international organizations most engaged and providing the fora for international diplomatic engagement have been principally the ILO and, to a lesser extent, the IMO. Over fifty relevant instruments have been developed under the auspices of the ILO since its founding just over a century ago. They deal with various subjects of obvious human rights relevance. Indeed, to a substantial extent, these ILO-generated instruments, most of which pre-dated the emergence of effective IHRL, have served to establish standards that may now be regarded mistakenly as deriving from notions of human rights. Regarding them in that way represents a great disservice to those who have long worked on seafarers' rights motivated by their knowledge and understanding of conditions at sea rather than their understanding of the finer

52 See Human Rights at Sea, Seafarers' Abandonment in the UAE (December 2018), available online: <https://www.humanrightsatsea.org/wp-content/uploads/2018/12/HRAS-Case -Study-UAE-Seafarer-Abandonment-Dec-18-SECURED.pdf> for the UAE case study and Human Rights at Sea, Eight Indian Seafarers Abandoned Off-shore Walvis Bay, Namibia, Face Fatigue, Lack of Wages and Mental Health Issues (January 2019), available online: $<$ https://www.humanrightsatsea.org/wp-content/uploads/2019/o1/HRAS_Case_Study _Abandonment_Walvis_Bay_Namibia_29_Jan_19_single_pages_SECURED.pdf> for the Walvis Bay example.

53 See Seafarers' Rights International, “Abandonment-The Warning Signs," available online: $<$ https://seafarersrights.org/seafarers-subjects/abandonment-of-seafarers/abandonment -the-warning-signs/>. 
points of IHRL. It is vitally important for those who come lately to a focus on the seas and oceans from an IHRL perspective to acknowledge the substantial effort that has already been devoted to the protection of those at sea through the work of labor and welfare organizations and the development of maritime labor law. There is much to be learned by both IHRL and maritime labor law specialists through constructive dialogue between them.

There is an interesting contrast which the author has detected (entirely subjectively, it needs to be said) between many of those involved in IHRL, on the one hand, and many of those involved in developing labor law, on the other. The former seem to have a tendency to look at the world as it is, to note that it is flawed and then to regard their principal role as being to change it. There is a strong idealistic motivation behind their approach. Those involved in developing and applying labor law, in contrast, look at the world as it is, also note its flaws, but realize that the best way of achieving progress is to shape policy and law around those flaws rather than wasting effort on fundamentally changing the world. They tend to be pragmatists rather than idealists and it is this that shapes their approach. Neither side of this divide has a monopoly of wisdom and there are clear lessons to be learned by each from the other. In no aspect of this subject is this observation more pertinent than it is in relation to enforcement.

By far the most significant ILO convention for the shipping industry today is the 2006 Maritime Labour Convention (2006 MLC), which entered into force in 2013 but which was amended in $2016 .{ }^{54}$ Those latest amendments demonstrate the extent to which labor law and IHRL overlap, with governments and shipowners expected to adopt measures to better protect seafarers against shipboard harassment and bullying. The $2006 \mathrm{MLC}$ is regarded as a "charter of rights" that seeks to ensure decent working arrangements for seafarers, no matter what their nationality, that of the ships on which they sail, or their location. It is supported by responsible shipowners because general compliance with it will ensure no ships can operate with sub-standard (and financially beneficial) working conditions for crews. As a convention, it is supported by governments because it combines a plethora of previously established legal

54 See International Labour Organization (ILO), "Maritime Labour Convention," available online: <https://www.ilo.org/global/standards/maritime-labour-convention/WCMS _667588/lang-en/index.htm> for a consolidated text and <https://www.ilo.org/dyn/ normlex/en/f?p=NORMLEXPUB:8ooo1:o > for a full list of those States that have ratified (numbering by 2021 just under one hundred, those that are parties including most of the major flag States). For an account of the process leading to the 2006 MLC, see Payoyo, n. 26 above. 
regulations in one up-to-date legal instrument that covers almost all aspects of seafarers' working conditions. ${ }^{55}$

While the 2006 MLC is a profoundly significant instrument in relation to maritime labor law, it has to be acknowledged that its direct relevance is to the shipping industry and to the five percent of the seagoing population employed within it. It is very early days yet, but the relatively recent extension of the ILO and IMO focus to the global fishing industry and the around 30 million fishers employed therein has the potential to be a "game changer" as far as working conditions are concerned. Of the six ILO conventions dealing with workers in the fishing industry, the most recent is the 2007 Work in Fishing Convention. ${ }^{56}$ It is to be hoped that this initiative eventually has the level of success attributed to the 2006 MLC. If it does, then it will arguably represent the main labor law influence on the totality of human rights at sea. What is clear is that these labor law instruments all have substantial relevance to human rights at sea.

\section{Refugee Law}

There is an argument that refugee law is simply a part of the body of IHRL and has no separate existence sufficient for it to be regarded as a separate regime of international law. This is clearly based on Articles 13, 14 and 15 of the Universal Declaration being the starting points for the law relating to refugees. Article 13 deals with freedom of movement between States, Article 14 deals with the right to seek asylum from persecution, and Article 15 deals with every person's right to a nationality. Nevertheless, a substantial body of law has been developed around these three provisions of the Universal Declaration and through the ${ }_{1951}$ Refugee Convention and its 1967 Protocol. As a consequence, there is now a substantial academic literature on the law relating to refugees, perhaps the most authoritative volume being that by Guy Goodwin-Gill, the doyen of academic lawyers dealing with the subject. As this article was being drafted the fourth edition of his standard text on the subject was in press (and due for publication before this present volume appears in print). ${ }^{57}$

55 ILO, Guidelines for Port State Control Officers Carrying out Inspections under the Maritime Labour Convention, 2006, (Geneva: ILO, 2009) available online: <https://www.ilo.org/ wcmsp5/groups/public/\%4oed_norm/\%4onormes/documents/publication/wcms _101787.pdf>.

56 See ILO, "List of Instruments by Subject and Status," available online: <https://www.ilo .org/dyn/normlex/en/f?p=1000:12030:0::NO:::\#Fishermen>.

57 The current edition is G. Goodwin-Gill and J. McAdam, The Refugee in International Law, 3 rd ed. (Oxford: Oxford University Press, 2007); the 4th edition is due for publication in September 2020, also by OUP. As if to demonstrate the substance of refugee law as a "special regime," another "standard" text is J. Hathaway, The Rights of Refugees under 
In brief, refugee law defines "refugees," provides for their protection, and establishes the principle of non-refoulement (under which no refugee is to be returned to any country where his or her life or freedom would be threatened on account of race, religion, nationality, membership of a particular social group, or political opinion.). ${ }^{58}$ This body of law has been brought into sharp relief by the recent and on-going flow of migrants transiting across the Mediterranean Sea from the MENA countries. The refugee law rights of movement and asylum together with the principle of non-refoulement have been combined with that part of the law of the sea dealing with safety of life at sea and search and rescue, to create a challenging and highly controversial set of circumstances, made all the worse by the activities of criminal groups offering to provide, at great cost, vulnerable men, women and children with seriously unsafe transport by sea. This situation is not unique; it has been encountered in the past and is likely to be repeated elsewhere in years to come. Refugee law must very clearly be one of the inputs to the special regime of human rights at sea.

\section{Other Potential Legal Input}

It would be vital going forward that a "special regime" of human rights at sea remained open to necessary and appropriate influence from any other relevant areas of international law. If it did not it would perpetuate the problem of fragmentation highlighted by the International Law Commission. One might also add, for example, consideration of the law relating to the prevention and suppression of transnational organized crime, especially that relating to human trafficking. International humanitarian law $(\mathrm{IHL})$ and the law of war and neutrality at sea are other closely related areas for consideration. ${ }^{59}$ Indeed, with those three bodies of law in mind, it may be appropriate to recognize a further special regime dealing with maritime security, the subject of the Kraska and Pedrozo volume mentioned above. Human rights at sea would need to remain "open" to input from other areas of law because otherwise it would

International Law (Cambridge: Cambridge University Press, 2005) which runs to 1,233 pages.

$5^{8}$ See Article 33 of the Convention Relating to the Status of Refugees, adopted 28 July 1951, in force 22 April 1954, 189 United Nations Treaty Series 137.

59 International humanitarian law $(\mathrm{IHL})$ is a term that is increasingly replacing "the law of war" and "the law of armed conflict." While this is not inappropriate in relation to armed conflict/war on land, it arguably remains problematic in relation to armed conflict/war at sea, principally, but not exclusively, to do with the enduring importance of the law of neutrality in that context. 
risk becoming a closed special regime of the sort that the ILC believed caused international law to fragment.

Is such a special regime, combining all the areas of law just described, necessary, as Papanicolopulu suggested? Would it bring anything new to the legal arrangements for ensuring human rights compliance? It is one thing to arrive at a novel way of describing an existing collection of legal rights and obligations, but quite another to add legal substance through such a combination. Fundamentally, is a newly defined special regime essential and will it bring forth any innovative legal arrangements? If it fails to do so, it is difficult adequately to justify. Before answering these questions, it will be useful to wait until after we have discussed the situation relating to enforcement jurisdiction.

\section{Enforcement Jurisdiction}

It is straightforward to indicate which States have enforcement jurisdiction in the various maritime juridical zones. It is more difficult for States to deliver against their responsibilities. There are two problems worth highlighting. The first is to do with enforcement and policing capacity within zones of coastal State jurisdiction. The second is to do with flag States' capacity to monitor and enforce standards on those vessels flying their flag globally, including on the high seas, where they expect—and are expected—to exercise exclusive jurisdiction.

Of the 193 member States of the UN, 145 are coastal States with maritime jurisdictional zones. A great many are less developed States, some of which are also small island developing States (SIDS) with extensive maritime domains. For well-developed and wealthy States, generating the capacity to police the waters under their jurisdiction is a straightforward matter, albeit one requiring determined investment. In stark contrast, economically challenged and what at the time of UNCLOS III were recently independent and less developed States, while attracted to the extension of their jurisdiction to seaward for the potential wealth it might generate, found the governance and regulation of their new found maritime domains difficult. Between those two extremes are many coastal States with a variety of constabulary capabilities. It is almost certainly the case that few if any coastal States currently have the physical wherewithal adequately to police their maritime domains with the monitoring and enforcement of human rights standards as a routine requirement. There is a need for capacity-building for law enforcement in general; human rights monitoring, compliance and enforcement all need in future to be accepted as an important part of that requirement. 
Far more concerning, however, is the situation on the high seas, where jurisdiction is exclusive to the flag State. It is doubtful whether any flag State has the physical capacity effectively to police its merchant fleet on the high seas. Even the major maritime powers with significant naval and coastguard forces would be stretched to achieve this. What is quite certain is that the world's largest open registries have absolutely no capacity whatsoever for doing so. This is a plain fact and, absent any radical review of the international ship registration system, this is not going to change. It is in this context where the distinction between idealistic human rights attitudes and more pragmatic maritime professional approaches becomes important, and where cross-fertilization of thinking between the two contrasting positions has utility. One has to be realistic and seek ways of monitoring and enforcing human rights standards on board vessels without relying on flag States taking direct action themselves while vessels are at sea. The answer seems obvious and involves regular ship inspections during port visits, employing port State control (PSC) measures for monitoring and compliance purposes. We know that PSC does work for a number of purposes associated with IMO technical conventions, with ships failing to meet the required standards suffering penalties as a consequence. An even more apposite example is the arrangement within the 2006 MLC for the monitoring and enforcement of its standards. International labor standards are effectively implemented at the working level and they are enforced. An obvious option, therefore, is a convention on human rights at sea negotiated under the auspices of the IMO and utilizing well-established PSC measures as a route to effective monitoring and enforcement. This is not yet on the IMO's agenda, but it ought to be.

So much for the shipping industry. When it comes to the monitoring and inspection of fishing vessels, the most obvious answer (though by no means a panacea) is to subject them to licensing conditions that include a human rights compliance provision, enforced by the coastal States in whose exclusive economic zones (EEZs) vessels are licensed to fish. High seas fishing would need to be covered by the various regional fisheries management organizations, although, as the UN Food and Agriculture Organization (FAO) admits, these are by no means all effective at policing the deep-sea fishing grounds. ${ }^{60}$

As a final comment, to illustrate the sort of common jurisdictional difficulty that arises, it is worth relating a story involving the Panamanian-registered cruise ship, the MSC Divina, cruising in the western Mediterranean in March 2019. A seventeen year-old British girl (under eighteen and, therefore,

6o See FAO, "Regional Fisheries Management Organizations and Deep-sea Fisheries," available online: <http://www.fao.org/fishery/topic/166304/en>. 
a minor) was apparently raped by an eighteen year-old Italian male. The vessel put into Valencia, the crime was investigated by the Spanish police and the case went before a Spanish court. Unfortunately, but quite correctly, the Spanish judge ruled that his court had no jurisdiction to try the case because the offence had occurred beyond Spanish jurisdiction, in Panamanian exclusive jurisdiction on board a Panamanian ship, while the vessel was steaming on the high seas. The accused was released and the victim of his assault was left with no effective remedy. Retired U.S. Coastguard Admiral, Fred Kenney, the Director of Legal Affairs for the IMO, when interviewed about the case, remarked, "There's no cut-and-dried rule. There is no international law that covers this situation at the moment." 61

\section{The Need for a Special Regime for Human Rights at Sea Confirmed}

Admiral Kenney's comment just quoted is enormously telling when it comes to answering the question posed earlier about the need for a special regime for human rights at sea. There is clearly a significant gap in the law, as evidenced by the case of the alleged sexual assault on board the MSc Divina. The enforcement of human rights standards at sea is a matter of profound concern. A legal regime in order to be consistent with the criteria for a functioning rule of law requires not only the law to exist but also the jurisdiction necessary to apply and enforce it. Gaps in the jurisdiction that allow for some to breach the law with impunity renders the law merely an illusion. If the defining of such a regime were merely stating what the law currently is, it would have little purpose beyond the presentational; it would certainly lack substantial purpose. The "special regime" we envisage here is not a means of stating what the law already is but, rather, a vehicle for advancing a coherent view of what the law ought to be. The special regime does not yet exist but it ought to be brought into existence. It is, in the Latin terminology traditionally favored by lawyers, a case of deliberately articulating de lege ferenda (a suggestion of what the law ought to be), rather than a statement lex lata (a reaffirmation of what the law presently is). The recognition of a special regime of human rights at sea would establish a framework of existing law and an agenda for its development to ensure effective application in all circumstances.

61 See E. Malkin, "Report of sexual assault on cruise ship shows gaps in international law," The New York Times (19 April 2019), available online: <https://www.nytimes.com/2019/o4/19/ us/cruise-ship-crimes-laws.html>. 


\section{A Program for Action}

The full program of action for ensuring compliance with human rights at sea needs to contain approaches at various levels. One way of looking at this is by way of a military analogy, focusing on three levels: the "strategic"; the "operational"; and the "tactical". Success at each being crucial for achieving success at the other two, they are most certainly interconnected. A measure of realism is required at each level, with action taken at the tactical needing to be consistent with and supportive of strategic objectives, but with those strategic objectives determined after taking into account what is either currently tactically feasible or potentially so. ${ }^{62}$ While strategy may be regarded as paramount in pursuit of an international objective, it will not be achievable unless it is based on a realistic understanding of what is possible at the lower operational and tactical levels. The description that follows of a hypothetical chain of action (to do with IHRL and fishing operations) may be useful to demonstrate how this may work in relation to human rights at sea. Pertinent examples at each level are as follows:

\section{Tactical}

Tactical action includes the response to an immediate threat of human rights abuses being committed on board fishing vessels within the EEZ of a coastal State. Ensuring that fishing is conducted within a framework for sound fisheries management requires coastal State authorities to maintain a constabulary presence on fishing grounds and to conduct a full range of routine operations within the EEZ - to both prevent/deter and respond to regulatory breaches. Under Article 62 of UNCLOS, the coastal State has an obligation to put in place measures for the effective implementation of a fisheries management regime, which includes the licensing of fishing activity. Those engaged in fishing (including the nationals of other States) are obliged to comply with "conservation measures and with the other terms and conditions established in the laws and regulations of the coastal State." ${ }^{33}$ Compliance with human rights standards in relation to the treatment and the protection of fishing

62 The author makes no apologies for utilizing military terminology and planning approaches here. In his experience of working in a military context and as a specialist in the development of military strategic doctrine, he believes that if applied with common sense and pragmatism, this is a most effective way of establishing priorities and setting a course for success.

63 United Nations Convention on the Law of the Sea (UNCLOS), adopted 1o December 1982, in force 16 November 1994, 1833 United Nations Treaty Series 3, Article 62.4 [emphasis added]. 
vessel crews can be included as a licensing condition. ${ }^{64}$ Civil society has a role to play in monitoring compliance and highlighting examples of breaches of human rights standards. There are difficulties for NG OS operating at sea, but it is by no means impossible, as a number (e.g., Greenpeace and Sea Shepherd) have demonstrated. Some NGO operations have been controversial in the past but, ideally, coastal State authorities and NGOs need to cooperate. That said, if maritime constabulary operations are well-run and effective, that will arguably obviate the need for NGO involvement. If human rights breaches are detected, the coastal State needs to have processes in place (including an effective policing presence on the fishing grounds) to conduct enforcement operations and to prosecute offenders.

\section{Operational}

At the operational level, coastal State governments need to put in place the necessary domestic legislation requiring fisheries license-holders to comply with human rights standards while operating in the EEz. ${ }^{65}$ This is needed to empower those enforcing fisheries regulations to take appropriate action against offending vessels. While this is not specifically provided for in UNCLOS, coastal States have the right to place conditions on the award and retention of licenses to fish in the context of responsible fisheries management.

\section{Strategic}

At the strategic level, States engage internationally on human rights issues and are also accountable for their own performance and compliance with IHRL. The UN human rights bodies perform an essential function in this respect, as do civil society organizations. Strategic action is to do with putting in place and maintaining an effective international system for ensuring human rights standards are established and maintained. Strategy is profoundly political and, while civil society performs an important monitoring function and will

64 The author is grateful to Irini Papanicolopulu for suggesting this link between fishing license conditions and IHRL. Indonesia has already adopted this approach, which took effect in 2017, with companies requiring human rights certification in order to fish within its EEz. See Business \& Human Rights Resource Centre, "Indonesia: Ministry Creates Certification Mechanism to Address Human Rights Abuses in Fishing Industry" (31 January 2017), available online: <https://www.business-humanrights.org/en/indo nesia-fisheries-ministry-creates-certification-mechanism-to-ensure-industry-is-free -from-human-rights-violations >.

65 See HRAS, Fishermen's Welfare and Human Rights: Ascension Island EEZ (HRAs International and Royal Society for the Protection of Birds, 2018), available online: <https:// www.humanrightsatsea.org/wp-content/uploads/2018/12/HRASi-RSPB-REPORT-Fisher mens-Welfare-and-Human-Rights-September-2018-SECURED.pdf >. 
certainly be engaged in advocacy, ultimately it requires the concerted engagement of States. Strategic action related to human rights compliance by fishers includes holding States to account through the international and UN human rights bodies. There may also be a need to put in place international agreements to facilitate State to State cooperation to do with the enforcement of IHRL. This could, for example, include arrangements for flag States to prosecute in relation to criminal breaches of human rights standards committed by their vessels operating in other States' E EZs. Oversight at the international strategic level will include the assessment of the adequacy of legislative and enforcement provision by States at the lower operational and tactical levels. The strategic level will fail to deliver if tactical enforcement capacity is inadequate.

Similar hypothetical accounts can be produced in relation to shipping and other sectors. In many cases, port States will have a key role to play in the enforcement of standards on board vessels entering their internal waters.

At the "tactical" level there will always be the need to monitor compliance with human rights standards at sea, coupled with the publicizing of both successes and failures as a means of advocacy. There is clearly a role for civil society in this endeavor, through the work of human rights NGOs, welfare organizations, trades unions and other bodies with a maritime focus.

There is a clear need for substantial engagement by States with human rights at sea. For the moment, their engagement is less than adequate and shortcomings need to be addressed by those involved in human rights advocacy. While individual States are important-be they identifiable as port States, coastal States or flag States - there can be little doubt that the issues associated with the advancement and protection of human rights at sea globally are unlikely to be met without collective engagement within the UN system. Human rights at sea need to be recognized as a fundamental concern within the UN organization as a whole and within relevant constituent elements of it. This means recognition at the highest level, within the Security Council and the General Assembly. It also means engagement within the UN human rights bodies, with those dealing with oceans and the law of the sea, and with shipping and fishing. To achieve this requires advocacy focused on New York (for the Security Council and the General Assembly), on Geneva (for the human rights bodies) and on London (for the IMO).

The following are potential strategic objectives for human rights at sea advocates to pursue, focused on the three centers of UN engagement: New York, Geneva, and London. All would raise the profile and awareness of human rights at sea: 
- Achieving the adoption of human rights at sea as a subject for regular UN Security Council open debates

- Ensuring that human rights at sea becomes a standing subject item for review in the annual UN General Assembly Resolution on Oceans and the Law of the Sea (adopted each December) ${ }^{66}$

- Securing a UN General Assembly declaration establishing an annual international day for human rights at sea

- Establishing human rights at sea as an agenda item for the Human Rights Council, including regular periodic review of the oceans (which currently fall outside the State-based arrangement for such reviews)

- Obtaining the appointment under "special procedures" of a special rapporteur with a thematic mandate on human rights at sea ${ }^{67}$

- Placing human rights at sea firmly on the IMo's agendas, in particular those of the Legal Committee and the Maritime Safety Committee ${ }^{68}$

- Achieving progress towards the negotiation of an IMO-sponsored convention on human rights at sea, to incorporate port State jurisdiction to facilitate monitoring, inspection and enforcement of IHRL standards on board merchant ships

\section{The Geneva Declaration on Human Rights at Sea}

These strategic objectives are important but they only make sense if they are supported by action at the operational and tactical levels. With this in mind, HRAS under David Hammond's leadership has devised the Geneva Declaration on Human Rights at Sea, which was launched in 2019 and endorsed by both the City and the Canton of Geneva. ${ }^{69}$ In endorsing it, they agreed to support

66 See, for example, UnGA, Resolution A/RES74/19 Oceans and the law of the sea (2019). It had been suggested that human rights at sea and the Geneva Declaration would be mentioned in the 2019 UNGA Resolution, but they were not included in the final text as voted in December 2019.

67 See онснв, "Special Procedures of the Human Rights Council," <https://www.ohchr.org/ en/HRBodies/SP/Pages/Welcomepage.aspx $>$.

68 On the Maritime Safety Committee, see Iмо, "Maritime Safety," available online: <https:// www.imo.org/en/OurWork/Safety/Pages/default.aspx $>$; on the Legal Committee, see Imo, "Legal Affairs," available online: <https://www.imo.org/en/OurWork/Legal/Pages/ Default.aspx $>$.

69 The original idea behind this was David Hammond's and he initiated the process that devised it. The first version, launched in 2019, involved a team of specialist legal academics on HRAs's Trustees and Advisory Boards (Haines, Mavropoulou, Papanicolopulu, Petrig and Galani) and a number of NGOs and other relevant agencies were invited to 
further development of the document by HRAS to include the promulgation of four detailed annexes. These provide evidence of human rights abuses, a detailed account of IHRL applicable at sea, a legal commentary on the Geneva Declaration, and an annex providing details of action to be taken to "operationalize" it. A revised second version was issued in March 2020 following comments received on the first version and is included as an Appendix to this article. It is likely now that this will remain in its current form, but that its four annexes will be kept under regular review as "living" instruments. ${ }^{70}$

The Geneva Declaration has the potential to become vital for advocacy purposes, principally at the strategic policy level. It is being given a wide circulation by HRAs to generate State support globally through individual States' declarations of support for the principles it contains. The hope is that States endorsing it will go on to champion human rights at sea within the relevant UN institutions in Geneva, New York and London. Its annex on "Operationalising Human Rights at Sea" is intended to be the principal guide to action. It promulgates in matrix form the actions required of port States, coastal States and flag States in ensuring IHRL is complied with and enforced in all the various zones of jurisdiction, including on the high seas. The matrix is intended not only as a guide to States on the actions they will need to take to ensure they meet their IH RL obligations, but also as a framework for audit and accountability. It will also provide clear indicators as to the actions required at the tactical level at which monitoring, prevention and enforcement takes place.

\section{Conclusion}

Human rights at sea as a "special regime" of international law is only just obtaining substance and recognition. It combines IHRL with the law of the sea and includes significant elements of maritime law, labor law and refugee law. It also remains "open" to the influence of other elements of international law. It is not as yet an effective regime, with much remaining to be done to ensure human rights standards are complied with on the seas and oceans. While human rights most certainly do apply at sea to the same extent that they

contribute to the drafting process. Meetings were hosted in Geneva by Marco Sassoli and the Geneva Academy of International Humanitarian Law and Human Rights, and by Andrew Clapham and the Graduate Institute for International and Development Studies.

70 The second edition has now been promulgated and an HRAs team is currently working on the four annexes to the Declaration, which will be kept under constant review. 
do on land, they are not being applied to the degree necessary for the seas to become a "safe space" for the over 30 million people who are present there.

There is no need for significant new law detailing the rights of those who are at sea; there is plenty already, but it needs to be complied with and enforced. There is, though, a place for additional conventional law detailing the process by which human rights at sea can be monitored and enforced. States, be they port States, coastal States or flag States, have sufficient jurisdiction in theory to take the necessary action but, in practice, far too many do not have the capacity to achieve adequate enforcement and until now have lacked the will and wherewithal to make the protection of human rights at sea a priority. They need encouragement and this needs to be delivered through international action within the UN system, especially from within the human rights bodies and relevant specialized agencies.

The potential strategic objectives listed above would serve to raise the profile and importance of human rights at sea at State and international levels. All of them are realizable and reflect similar developments that have been pursued in relation to other pressing IHRL needs. Ultimately, however, it is what happens at sea that matters. Individual States need to confront their responsibilities and obligations to those whose rights are being denied or abused. Governments need to be held accountable and civil society has a vital role to play in monitoring compliance with human rights standards.

For over three centuries the dominant approach to ocean governance has been what Grotius termed Mare Liberum or the freedom of the seas. What is needed today and into the future is not so much free seas as safe and secure seas. A move perhaps from Mare Liberum to what we might instead refer to as Mare Legitimum, or lawful seas, with respect for human rights as a fundamental part of what that implies.

\section{Appendix: Geneva Declaration on Human Rights at Sea}

Version 2 (March 2020)

\section{Preamble}

The seas and oceans cover $70 \%$ of the earth's surface. Activity at sea, both legitimate and unlawful, is increasing year-on-year. This is leading to an increase in the number of people at sea, currently estimated to be around 30-40 million men, women and children at any given moment.

The majority of these people are fishers, approximately 30 million, an estimated 20,000 of whom are children working at sea and in coastal fisheries. Others are in shipping, in offshore oil and gas, and in the tourism industry. There are also passengers, 
holiday-makers and scientists. Further, there are increasing numbers of people using the seas and oceans as a means of migration. Finally, there are people involved in illegal activities.

There is significant and growing evidence of widespread, deliberate and often systematic abuse of human rights at sea. Examples are: fishers, including young children, held in slavery on fishing grounds thousands of miles away from their families and home State; seafarers abandoned without pay or compensation; victims of sexual assault on board passenger and cruise ships often left without legal protection or effective remedy; migrants and refugees, including children, trafficked by unscrupulous criminals in life-threatening conditions; and people suspected of wrongdoing subjected to the use of excessive force and arbitrary detention without lawful oversight.

People are disappearing, they are dying, they are being assaulted and abused at sea. If such human rights violations were occurring ashore, they would be well-publicised and addressed. However, they are happening at sea, out of sight of land, and those who could act to stop them are not always aware of the problem.

Human rights abuses at sea are frequently not reported, enforced or remedied because of the challenging nature of the maritime environment. Abuses often occur far away from State authorities, the sea is a vast area to monitor, and policing is too frequently ineffective due to a lack of resources, or the willingness to take action.

While the seas and oceans are a challenging environment and have unique characteristics that demand unique responses, this emphatically does not mean that human rights can be compromised in any way. The seas are free for all legitimate purposes; the abuse of human rights at sea is not a legitimate purpose in any circumstance.

People at sea are full beneficiaries of human rights, the fact that they may be at sea beyond the limits of territorial jurisdiction does not affect their human rights.

The time to act has come. A legal order ensuring safe and secure seas and oceans requires that all people at sea enjoy human rights, that violations are effectively addressed, and that victims are provided with an effective remedy. The public order of the oceans, including the protection of human rights for all people, is a collective responsibility of the international community.

It is primarily States that have responsibility for enforcing human rights standards at sea, in particular, flag States, coastal States and port States.

Other actors, such as international organisations, non-governmental organisations, civil society bodies, private companies, masters of vessels, security personnel on board vessels and consumers also need to recognise and act upon their own roles in the protection of human rights at sea.

\section{Aim}

The aim of the Geneva Declaration on Human Rights at Sea is to recall existing legal obligations, to raise global awareness of human rights abuses at sea, to generate a 
concerted international response to them and to ensure an effective remedy for those who are abused.

\section{Fundamental Principles}

The protection of human rights at sea rest on the following four fundamental principles:

- Human rights apply at sea to exactly the same degree that they do on land.

- All persons at sea, without any distinction, are entitled to their human rights.

- There are no maritime specific rules allowing derogation from human rights.

- All human rights established under treaty and customary international law must be respected at sea.

\section{About Human Rights at Sea}

Human rights are universal; they apply at sea, as they do on land.

The presence, in increasing numbers of people on the seas and oceans, generates a growing need for their protection against threats to their human rights, which apply to the same extent at sea as they do on land. Nobody is in a human rights vacuum.

Sadly, however, it is a harsh fact that not all those at sea find themselves under the effective jurisdiction of States capable of protecting their human rights and willing to do so. The result is that a great many who are vulnerable end up being abused, with those doing the abusing escaping the consequences of their actions.

While effective remedy is difficult to achieve in relation to human rights at sea, an important aim of this Declaration is to ensure that it will be achieved.

Enforcing human rights standards at sea is problematic, with the territorial jurisdiction of States only extending to 12 nautical miles from the shore. Well over $60 \%$ of the Earth's surface is, therefore, beyond the limits of States' territory. If human rights at sea are to be respected, complied with, and enforced, all States need to accept their extraterritorial obligations on the oceans.

Human rights belong to all individuals, regardless of race, colour, sex, language, religion, political or other opinion, national or social origin, property, birth, occupation or other status.

Human rights at sea are reflected in the 2011 UN Guiding Principles on Business and Human Rights and are supported in the UN Sustainable Development Goals.

The seas and oceans are a public space, which is crossed by vessels and people from all States, and different States exercise their jurisdiction thereon.

The 'international community' consists of individual States, none of which should abdicate their share of the international community's collective responsibility for human rights standards at sea. States also need to act individually, as well as collectively, when necessary.

The notion that human rights apply at sea is not a new one, but the seas and oceans have not been the focus of human rights processes to the same extent as States ashore. 
The concept of human rights at sea as outlined here is a new way of articulating human rights issues at sea, of raising global awareness of the problem, and of highlighting the need for concerted international action. Human rights at sea have not been adequately recognised in the past; they must be in the future.

This Declaration reflects existing conventional and customary international law as well as general principles and proposes no new law relating to human rights at sea. The fundamental principles of human rights law already exist but it is manifestly the case that they are not universally respected, they are not universally complied with, nor are they adequately enforced.

This Declaration is also consistent with the 1982 UN Convention on the Law of the Sea. The protection of human rights and their enforcement at sea in no way undermines the long-standing understanding of the freedom of the seas. On the contrary, the respect for and enforcement of human rights at sea is essential if the freedom to use the seas for legitimate purpose is to be maintained effectively. Safe, secure and well-ordered seas and oceans are essential for the international community to enjoy the use and resources of the oceans in a responsible and sustainable manner.

\section{Annexes to the Declaration}

NOTE: The following four Annexes to the Geneva Declaration are "living" documents; they are regularly reviewed and updated in order that they remain as up to date as possible. For that reason, they are not included in this article. The latest iterations are available on the following HRAS subsidiary website dedicated to the Declaration: https://gdhras.com/.
A. Contemporary Evidence of Human Rights Abuses at Sea
B. List of Applicable Human Rights at Sea
C. Commentary
D. Operationalising Human Rights at Sea 